\title{
Mutation detection for exons 2 to 10 of the Polycystic Kidney Disease 1 (PKD1)-gene by DGGE
}

\author{
Dorien JM Peters ${ }^{*}{ }^{1}$, Yavuz Ariyurek ${ }^{1}$, Marjan van Dijk ${ }^{2}$ and Martijn H Breuning ${ }^{1}$ \\ ${ }^{1}$ Department of Human and Clinical Genetics, Leiden University Medical Center, Leiden, The Netherlands; \\ ${ }^{2}$ Department of Nephrology, Leiden University Medical Center, Leiden, The Netherlands
}

The PKD1-gene encodes a $14 \mathrm{~kb}$ transcript spanning a $50 \mathrm{~kb}$ genomic interval. Two-thirds of the gene is reiterated at another locus on the same chromosome. Using Long Range PCR with primers in intron 1 and exon 11, 6.8 kb PKD1 specific fragments were generated on genomic DNA. These products were used as templates for nested PCR's to screen exons 2-10 by Denaturing Gradient Gel Electrophoresis (DGGE). Upon analysis of $\mathbf{3 6}$ patients, a total of 11 different sequence variants were observed: A nonsense mutation in exon 2, a frameshift mutation in exon 8 and furthermore, two amino acid changes, two silent polymorphisms and five intronic variants.

European Journal of Human Genetics (2001) 9, 957-960.

Keywords: Polycystic kidney disease; ADPKD; PKD1; DGGE

\section{Introduction}

Autosomal Dominant Polycystic Kidney Disease (ADPKD) has an incidence of 1 in 1000 in Caucasians. The formation of a large number of fluid-filled cysts in both kidneys together with interstitial fibrosis usually causes chronic renal failure in $50 \%$ of patients by the age of 60 years. Frequently occurring extra-renal manifestations are hypertension, cysts in liver and pancreas, and the occurrence of cerebral aneurysms. In $85 \%$ of ADPKD-families the disease is caused by a mutation in the $P K D 1$-gene. ${ }^{1}$ These patients have a more severe progression of the disease compared to patients with a mutation in the $P K D 2$-gene. ${ }^{2}$

A large part of the $P K D 1$-gene is reiterated at another locus on chromosome $16 \mathrm{p}$, hampering mutation detection using straightforward techniques. ${ }^{3}$ The unique $3^{\prime}$ part of the gene, exons 34-46, harbours only $10 \%$ of the mutations. ${ }^{4}$ Basically, the strategy to screen the reiterated part of the gene is to use long-range PCR with primers in unique parts of the gene, followed by nested PCR reactions

${ }^{*}$ Correspondence: Dorien JM Peters, Department of Human and Clinical Genetics, Leiden University Medical Center, Wassenaarseweg 72, 2333AL Leiden, The Netherlands. Tel: 3171 5276048; Fax: 3171 5276075;

E-mail: d.j.m.peters@lumc.nl

Received 11 September 2001; revised 8 November 2001; accepted 9 November 2001 to amplify the different exons. ${ }^{5,6}$ We describe here the screening of exons $2-10$ by DGGE in 12 overlapping fragments.

\section{Methods \\ Patients}

In this study we analysed DNA from 36 individuals diagnosed as having ADPKD, 25 linked to the PKD1-gene on chromosome 16, other families are too small to establish linkage. The majority of patients have been analysed for most of exons 15 and $23-46$.

PCR amplification of DNA

LR-PCR was performed, in $50 \mu \mathrm{l}$ reactions, using the EXPAND $^{\mathrm{TM}}$ PCR system (Roche, Mannheim, Germany) with buffer system 3 containing: $2.25 \mathrm{mM} \mathrm{MgCl}_{2}, 50 \mu \mathrm{M}$ of each dNTP, $300 \mathrm{nM}$ of each primer (pPKDin1AF and pTr) and $250 \mathrm{ng}$ genomic DNA. Samples were amplified in $0.2 \mathrm{ml}$ thin-walled tubes using a Perkin Elmer DNA thermocycler (Geneamp PCRsys 2400, PE Applied Biosystems, Nieuwerkerk a/d/ IJssel, The Netherlands). The PCR programme recommended by the manufacturer was used with denaturing, annealing and elongation temperatures of 94,66 , and $68^{\circ} \mathrm{C}$ respectively and elongation times of $10 \mathrm{~min}$ increasing with 20 s per cycle. 
Nested PCR's for exons 2-10 were performed on the $6.8 \mathrm{~kb}$ pPKDin1aF-pTr products isolated from gel using low meltingpoint (LMP) agarose. Samples were always loaded with empty lanes in between. Nested PCR's were performed on $10^{5}$ times diluted products with intronic primers to amplify all exons and adjacent splice and branch sites. Primers were selected using the melt map programme WINMELT version 2.0. For each fragment a 50 or 55 bp GC-clamp was attached at the $5^{\prime}$ or 3 ' end of one of the primers.

A single set of primers was used for each exon except for exons 5 and 10 where two and three pairs were needed respectively (Table 1 ).

Denaturing gradient gel electrophoresis (DGGE)

Amplified fragments were analysed on a 9\% polyacrylamide gel (37.5 : 1; Mallinckrodt-Baker, Deventer, The Netherlands) with linear denaturing gradients of 40 to $100 \%$ of a mixture of $40 \%$ formamide (Mallinckrodt-Baker) and $7 \mathrm{~m}$ urea (USB, Amersham Pharmacia Biotech, Roosendaal, The Netherlands), for details see Table 1. Electrophoresis was performed at a constant temperature of usually $58^{\circ} \mathrm{C}$, at $100 \mathrm{~V}$ for $8-$ $16 \mathrm{~h}$.

\section{Results}

Alignment of the PKD1 genomic sequence and the sequence of a Bacterial Artificial Chromosome (BAC) clone that contains two copies of the homologous loci (Genbank AC002039), was previously shown to reveal regions in the $P K D 1$-gene that were not duplicated in the two homologous genes. ${ }^{7}$ In one of these regions in intron 1 , close to exon 2 , we selected a PCR primer for long-range PCR (pPKDin1AF). The other primer (pTr) is located in exon 11. To validate specificity of the amplified products radiation hybrid HJ145.19, which contains only the PKD1-gene and the rodent-human somatic cell hybrid N23HA, which contains only the homologous region, were used as controls. ${ }^{3}$ Longrange PCR revealed in human DNA a $6.8 \mathrm{~kb}$ band that was also present in HJ145.19 but absent in N23HA (Figure 1). In addition a $1.2 \mathrm{~kb}$ band was observed sometimes in N23HA, although with varying intensities. This band was always absent in HJ145.19, indicating that it may be a product of one of the copies of the PKD1 gene at a proximal location on chromosome 16 (Figure 1). We therefore always isolated the $6.8 \mathrm{~kb}$ band from a low melting point agarose gel, and nested PCR's were performed on a $10^{5}$ dilution of this product. Nested PCR's never revealed products on the $6.8 \mathrm{~kb}$ region isolated from gel in the N23HA control somatic cell hybrid (not shown).

\section{Denaturing gradient gel electrophoresis for PKD1 exons 2} to 10

For DGGE-analysis gene-specific fragments of $119-372$ bp were generated. A single set of primers was used for each exon

Table 1 Primers and DGGE conditions

\begin{tabular}{|c|c|c|c|c|}
\hline Primer name & Sequence $\left(5^{\prime}-3^{\prime}\right)$ & Size (bp) & Tann. $\left({ }^{\circ} \mathrm{C}\right)$ & DGGE conditions \\
\hline $\mathrm{ex} 2 \mathrm{~F}$ & $\mathrm{~b}_{\text {AGGCCATAGCTTGGGGATGC }}$ & 193 & 60 & $9 \%$ PAA $40 \%-100 \%$ UF $58^{\circ} \mathrm{C}$ \\
\hline ex2R & CACGACTGGGGGACACTCAC & & & \\
\hline ex3F & GGCTCCTGGCGAACCTCTCG & 262 & 55 & $6 \%$ PAA $40 \%-70 \%$ UF $58^{\circ} \mathrm{C}$ \\
\hline ex4F & $\mathrm{a}_{\text {GGCATAGACCCTTCCCACCAGA }}$ & 340 & 60 & $9 \%$ PAA $40 \%-100 \%$ UF $58^{\circ} \mathrm{C}$ \\
\hline ex4R & ACTCACAGGCTCCCATGCT & & & \\
\hline $\mathrm{ex} 5 \mathrm{aF}$ & ${ }^{a}$ AGCATGGGAGCCTGTGAGT & 372 & 55 & $9 \%$ PAA $40 \%-100 \%$ UF $58^{\circ} \mathrm{C}$ \\
\hline ex5bR & СтTCCACCTGCACGTCTGT & & & \\
\hline $\mathrm{ex} 5 \mathrm{cF}$ & CTCGCATCGCTATGTGCTGC & 337 & 60 & $9 \%$ PAA $40 \%-100 \%$ UF $58^{\circ} \mathrm{C}$ \\
\hline ex5cR & 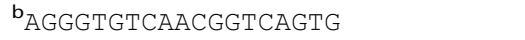 & & & \\
\hline ex6F & GCAGAGCCTGGTACCCCCGT & 346 & 55 & $9 \%$ PAA $40 \%-100 \%$ UF $58^{\circ} \mathrm{C}$ \\
\hline ex6R & ${ }^{\mathrm{C}}$ АССТССTTCСТCCTGAGACT & & & \\
\hline ex7F & GGAAAGGGGGACAGTGATGGG & 395 & 60 & $9 \%$ PAA $40 \%-100 \%$ UF $58^{\circ} \mathrm{C}$ \\
\hline ex7R & CCAGGCTCCACCGCGGGCGC & & & \\
\hline ex10aR & CGGGAACGGAGAAGAGGA & & & \\
\hline ex10bF & TCTGCTTGCCGCTGGACGCC & 119 & 64 & $9 \%$ PAA $40 \%-100 \%$ UF $58^{\circ} \mathrm{C}$ \\
\hline ex10bR & $\mathrm{b}_{\text {GGGAACGGAGAAGAGGAA }}$ & & & \\
\hline PKDint1 af & GGG GAG GTG GAG TTC TCG GTT TGC C & & & \\
\hline $\mathrm{p} \operatorname{Tr}$ & CCT CCA AGT AGT TGC GCT GTG ATC G & & & \\
\hline
\end{tabular}



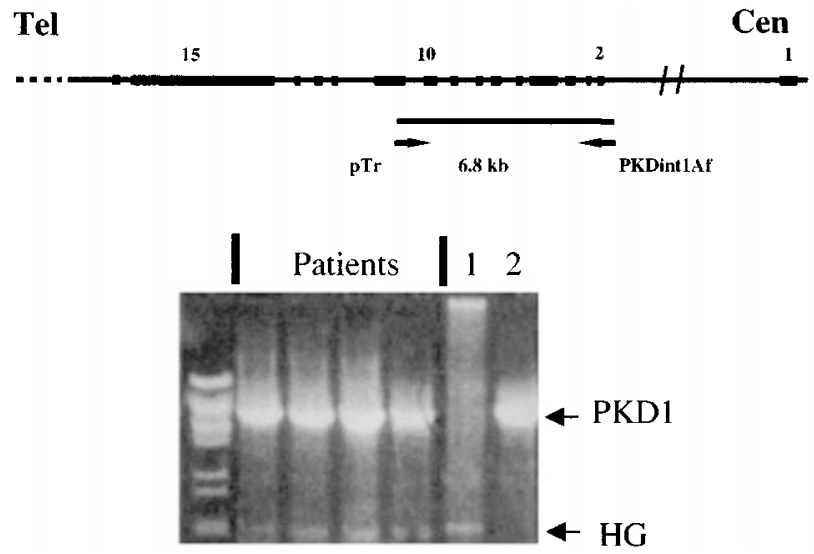

Figure 1 Long Range PCR. LR - PCR for exon 2-10, with primers PKDint $1 \mathrm{aF}$ in intron 1 (position 17621) and $\mathrm{p} \operatorname{Tr}$ (position 24449 ) in exon 11, generates a $6.8 \mathrm{~kb}$ fragment for the PKD1gene and a $1.2 \mathrm{~kb}$ fragment for a homologous locus (HG). (1) Hybrid cell line N23HA, contains the homologous loci (HG) and not the PKD1-gene. (2) Hybrid cell line HJ145-19, contains the $P K D 1$-gene and not the HG-loci.

except for exons 5 and 10 where two and three pairs were needed respectively. A total of 11 different sequence variants were observed (Table 2) that were confirmed on fresh LRPCR's followed by nested PCR's on DNA of the patients and/ or additional family members.

Truncating mutations Analysis of exon 5 (fragment 5C) revealed a nonsense mutation in family PK4. This mutation, R400X predicts a translation stop at amino acid 400 and generates a DdeI restriction site. The index patient of this family died at 68 years of age from cardiac infarction. Polycystic kidneys were an unexpected finding at autopsy. In total 15 affected family members were collected, two of them reached end stage renal failure (ESRF) before 50 years.

Analysis of exon 8 revealed a frame shift mutation in family PK10. Deletion of a C in a stretch of 4C's at position $1703-1706$, predicts a frame shift at amino acid 596 resulting in a truncated protein of 610 amino acids. The index patient was a male, with polycystic kidney and liver disease, who entered into renal failure at 69 years and died at the age of 72 due to heart failure. He had six children with polycystic kidney disease. One of them entered into renal failure at the age of 31 .

Coding and non-coding polymorphisms Two amino acid substitutions were identified: $276 \mathrm{G}>\mathrm{A}$ in exon 2 , resulting in the amino acid substitution $\mathrm{A} 92 \mathrm{~T}^{4}$ was once identified. $1919 \mathrm{C}>\mathrm{T}$, in the overlap of fragments ex10A and ex10B, results in the substitution $\mathrm{A} 637 \mathrm{~V}$ and was identified in four families including family 10 for which we identified a frame shift mutation in exon 8 (see above). Analysis of exon 5
Table 2 Mutations and polymorphisms. Mutations and polymorphisms were designated according to the recommendations of Antonorakis et al (13) using the PKD1 sequence with Genbank accession number U24498

\begin{tabular}{|c|c|c|c|}
\hline \multicolumn{4}{|l|}{ Mutations: } \\
\hline Nucleotide change & Amino acid change & Exon & Patient \\
\hline $1998 C>T$ & R400X & 5 & PK4 \\
\hline 1706delC & fs596 (stop at 610) & 8 & PK10 \\
\hline \multicolumn{4}{|l|}{ Polymorphisms: } \\
\hline & & Exon & Frequency \\
\hline $276 G>A$ & А92T & 2 & $1 / 72$ \\
\hline $1910 \mathrm{C}>\mathrm{T}$ & A637V & 10 & $4 / 72$ \\
\hline $1023 C>T$ & A341A & 5 & $2 / 72$ \\
\hline \multirow[t]{2}{*}{$1120 \mathrm{~T}>\mathrm{A}$} & L373L & 5 & $1 / 72$ \\
\hline & & Intron & \\
\hline $216-79 C>T$ & - & 1 & $2 / 72$ \\
\hline $1620-39 C>T$ & - & 7 & $1 / 72$ \\
\hline $1722+23 C>T$ & - & 8 & $1 / 72$ \\
\hline $1723-27 \mathrm{G}>\mathrm{A}$ & - & 9 & $11 / 72$ \\
\hline $1850-4 G>T$ & - & 9 & $6 / 72$ \\
\hline
\end{tabular}

revealed two silent mutations $1023 \mathrm{C}>\mathrm{A}$ (A341A) and 1120T > A (L373L) both also described by Rosetti et al. ${ }^{4}$ Five intronic polymorphisms in introns $1(216-79 \mathrm{C}>\mathrm{T})$, $7(1620-39 \mathrm{C}>\mathrm{T}), 8(1722+23 \mathrm{C}>\mathrm{T}$ and $1723-27 \mathrm{G}>\mathrm{A})$ and $9(1850-4 \mathrm{G}>\mathrm{T})$ were observed with varying frequencies.

\section{Discussion}

We have performed mutation detection for the PKD1-gene to gain insight into the mutation spectrum but also for diagnostic applications in ADPKD patients. Sequencing the entire 14 kilobases of coding DNA of the PKD1 gene is a daunting task. We therefore prefer to pre-screen fragments of the gene searching for variants. We have chosen to screen the PKD1-gene by DGGE because the sensitivity to detect sequence variants can reach to a value close to $100 \%$ when a GC-clamp is introduced in the fragment during PCR. ${ }^{8}$ Exons 2-10 comprise approximately $1.7 \mathrm{~kb}(13 \%)$ of coding sequence in which we identified two (5\%) truncating mutations in 36 patients and several variants were identified which are likely to be non-disease causing polymorphisms. These data are in a similar range as observed by Rosetti et al. ${ }^{4}$ who screened the same region of the gene by direct sequencing. However, Phakdeekitharoen et al. ${ }^{9}$ did not find any mutation in this part of the gene by heteroduplex analysis in 40 Thai families. DGGE-analysis for other parts of the gene have been reported previously. ${ }^{10,11}$

All the available data suggest that with a few exceptions ${ }^{4}$ each family with ADPKD has its own 'private' mutation. The mutation detection rate for the gene as a whole is around $60 \%$ 
indicating that promotor mutations, missense mutations, deletions or variants with unknown effects on splicing may also be responsible for the disease. So far the mutations appear to be spread evenly over the entire $P K D 1^{4,11}$ and also $P K D 2^{12}$ gene with no clustering indicative of mutation hot spots.

\section{Acknowledgments}

This research was supported by a grant from the Dutch Kidney Foundation (C95-1511). The authors thank patients and clinicians for participation in the study, MP Villerius from the Leiden Genome Technology Center for sequencing, L Spruit for technical assistance and $S$ White for critical reading of the manuscript.

\section{References}

1 Peters DJM, Sandkuijl LA: Genetic heterogeneity of polycystic kidney disease in Europe; in Breuning MH, Devoto M, Romeo G, (eds): Contributions to Nephrology, Vol. 97: Polycystic Kidney Disease. Basel: Karger; 1992, pp 128-139.

2 Hateboer N, Dijk MA, Coto E et al: Comparison of phenotypes of polycystic kidney disease types 1 and 2. European PKD1-PKD2 Study Group. Lancet 1999; 353: $103-107$.

3 The European Polycystic Kidney Disease Consortium: Ward C, Peral B, Hughes J, Thomas S, Gamble V, MacCarthy A et al: The polycystic kidney disease 1 gene encodes a $14 \mathrm{~kb}$ transcript and lies within a duplicated region on chromosome 16. Cell 1994; 77: $881-894$

4 Rossetti S, Strmecki L, Gamble V et al: Mutation analysis of the entire PKD1 gene: genetic and diagnostic implications. Am J Hum Genet 2001; 68: 46-63.
5 Watnick TJ, Piontek KB, Cordal TM et al: An unusual pattern of mutation in the duplicated portion of PKD1 is revealed by use of a novel strategy for mutation detection. Hum Mol Genet 1997; 6: $1473-1481$.

6 Peral B, Gamble V, Strong C et al: Identification of mutations in the duplicated region of the polycystic kidney disease 1 (PKD1) gene by a novel approach. Am J Hum Genet 1997; 61: 13991410 .

7 Thomas R, McConnell R, Whittacker J, Kirkpatrick P, Bradley J, Sandford R: Identification of mutations in the repeated part of the autosomal dominant polycystic kidney disease type 1 gene, PKD1, by long-range PCR. Am J Hum Genet 1999; 65: 39- 49.

8 Sheffield VC, Cox DR, Lerman LS, Meyers RM: Attachment of a 40-base-pair $\mathrm{G}+\mathrm{C}$-rich sequence (GC-clamp) to genomic DNA fragments by the polymerase chain reaction results in improved detection of single-base changes. Proc Natl Acad Sci USA 1989; 86: $232-236$.

9 Phakdeekitcharoen B, Watnick TJ, Germino GG: Mutation analysis of the entire replicated portion of pkd1 using genomic dna samples. J Am Soc Nephrol 2001; 12: 955 - 963.

10 Perrichot RA, Mercier B, Simon PM, Whebe B, Cledes J, Ferec C: DGGE screening of PKD1 gene reveals novel mutations in a large cohort of 146 unrelated patients. Hum Genet 1999; 105: 231 239.

11 Perrichot R, Mercier B, Quere I et al: Novel mutations in the duplicated region of PKD1 gene. Eur J Hum Genet 2000; 8: 353 359.

12 Veldhuisen B, Saris JJ, de Haij S et al: A spectrum of mutations in the second gene for autosomal dominant polycystic kidney disease (PKD2). Am J Hum Genet 1997; 61: 547-555.

13 Antonarakis SE: Recommendations for a nomenclature system for human gene mutations. Nomenclature Working Group. Hum Mutat 1998; 11: 1-3. 